\title{
VJEROVANJA U NADNARAVNA BIĆA
}

\author{
Petra KELEMEN \\ Filozofski fakultet Sveučilišta u Zagrebu \\ Odsjek za etnologiju i kulturnu antropologiju \\ Ivana Lučića 3, 10000 Zagreb
}

\section{UVOD}

Tstraživanje duhovne kulture stanovnika pojedinog kraja za svakog etnologa predstavlja poseban izazov. Spremnost na razgovor o temama koje često otkrivaju vrlo osobna iskustva kazivača, njihove stavove i vjerovanja, odlučujuća je u okviru takvog terenskog istraživanja. Zahvaljujući izrazitoj susretljivosti i otvorenosti kazivača, istraživanjem vjerovanja u nadnaravna bića na području Krivoga Puta dobiveno je mnoštvo podataka. ${ }^{1}$ Priče o vilama, viškama, morama, zapisi o vampirima i vukodlacima, mračnjacima i vrimenjacima te pojedina kazivanja o neobičnim, neobjašnjivim događajima čine središte ovoga prikaza prikupljenih podataka. ${ }^{2}$ Razlike koje postoje u odgovorima kao i činjenica da su o nekim pojavama dobiveni odgovori samo od pojedinih kazivača, upućuju na važnost uvažavanja osobnog iskustva i razmišljanja kazivača, iako se, naravno, ponegdje mogu nazrijeti i zajedničke crte u kazivanjima.

\section{LIPA KO VILA}

$\mathrm{V}$ ile su bića uz koja nitko od kazivača nije vezao ništa negativno. Jedino je Kata Pavelić Burgijina iz Pavića navela kako su djecu plašili govoreći im odnit će te vila. Kazivači su vile okarakterizirali kao visoke, lijepe, ${ }^{3}$ kao mlade djevojke ${ }^{4}$. Anka Vukelić Matićeva iz Rupe pridodala je kako su djevojke znali uspoređivati s vilama: ...lipa ko vila. Ko vila nagorkinja oni su znali reć. Vile su, prema riječima kazivača,

1 Pri terenskom istraživanju podaci su prikupljeni na sljedećim lokalitetima: Gorica, Katići, Krivi Put, Kuljići, Lucići, Mrzli Dol, Pavelići, Pavići, Popići, Rupa, Rusova Draga, Serdari, Škopci, Šojatski Dolac, Šolići, Špalji, Veljun, Žuljevići. Pri prvom istraživanju sudjelovala je kolegica Marija Brajković koja je skupila vrijedne podatke i napravila početnu sintezu građe. Pojedina vjerovanja u svom tekstu u ovoj monografiji pod nazivom Vjerovanja vezana uz odabir bračnoga druga i zaštitu mladenaca donosi Sanja Lončar.

2 Ispitivanje ove teme tražilo je ponajviše primjenu tehnike nestrukturiranog intervjua, zahvaljujući kojoj su kazivači iznijeli važna osobna iskustva i razmišljanja. Kao pomoć u pripremi za istraživanje poslužila je Upitnica Etnološkog atlasa Jugoslavije, svezak IV, teme broj: 141. Mora, vampir, vukodlak i neka slična bića, 142. Vještice, vile, sudenice, 143. Neka druga natprirodna bića i pojave, 149. Zlo oko, uroci, sretni i nesretni dani. Uz pojedina kazivanja prikazat će se i podaci prikupljeni ovim upitnicama (signatura Krivoga Puta: Fd 241, zapisivač Slobodan Šimić, kazivač Milan Krmpotić). Uz to što u upitnicama nije navedeno na koje se krivoputske zaseoke kazivanja odnose, već se i samim bilježenjem kazivanja samo jednoga kazivača dobiva generalizirana slika, kakva se nastojala izbjeći terenskim istraživanjem vjerovanja u nadnaravna bića kojim se željela zabilježiti raznolikost osobnih iskustava, vjerovanja, mišljenja, sjećanja, priča. Nevena Škrbić u svom članku izvješće s istraživanja u selima pod Senjskim bilom i u zaledu Sv. Jurja (2001) u poglavlju Viške, uroci i žene koje znadu izgovarat donosi podatke o pojedinim segmentima vjerovanja u nadnaravna bića koji su obrađeni u ovome radu. Podaci koje je iznijela autorica, značajni su i zbog toga što su zabilježeni u novije vrijeme, vezani su uz područje koje nastanjuju primorski Bunjevci te postoji mogućnost komparacije $s$ podacima prikupljenima na području Krivoga Puta. No, kako osnovna namjera mojega rada nije bila uklapanje pojedinih vjerovanja i zabilježenih sjećanja u širi prostorni kontekst, u tekstu nisam detaljnije upućivala na autoričine podatke.

3 Ove je karakteristike naveo Anton Prpić Matin iz Veljuna. Eleonora Prpić Lejina iz Veljuna kazala je kako su bile visoke, velike. Anka Vukelić Matićeva iz Rupe naglasila je njihovu ljepotu.

4 O vilama kao djevojkama govorili su: Anka Vukelić Matićeva, Rupa; Grgo Prpić Miškec, Gorica; Zdenka Pavelić Vranićeva, Pavići. 
obučene u bijelo, ${ }^{5}$ imaju dugu kosu, ${ }^{6}$ za koju je Milan Prpić Popić iz Popića potvrdio da je plave boje, dok je Anton Prpić Matin iz Veljuna kazao kako su je vile plele u pletenice. Tome Špalj Cucin iz Krivoga Puta naveo je kako se djevojkama znalo reći da su kao vile kad bi raspustile kosu: Kad bi prije neka djevojka imala, prije se nije šišalo, kaže, vidi je, ima kosu ko bijela vila, onda to njima drago bilo. Milan Prpić Markin iz Veljuna uz vile je vezao sjaj, kazao je kako su bile obučene u sjajnu lepršavu haljinu te kako su na glavi imale ko svetlo, slično kao ono što sveci nose, sjajno. Ivan Prpić Kavarica iz Lucića uz dugačku bijelu haljinu spomenuo je i šlajer koji je bio dugačak poput haljine. Često spominjana karakteristika vila su i njihove noge; naime, kazivači su naveli kako one nisu imale ljudske noge, već kopita, noge mule ili konja. ${ }^{7}$ Ivan Prpić Kavarica iz Lucića i Milka Prpić Markina iz Veljuna kazali su kako su vile prvale (vrtjele).

Uz vile su kazivači redovito vezali njihov ples u kolu. ${ }^{8}$ Pojedinci su naglasili kako su u prirodi bila vidljiva mjesta na kojima su vile plesale. ${ }^{9}$ Eleonora Prpić Lejina iz Veljuna pojasnila je: Kada bi onda onako malo zelenija trava u obliku kola, kruga, veli, tu su vile kolo plesale. Zdenka Pavelić Vranićeva iz Pavića jedina je navela kako su vile kolo plesale na raskrižjima te kako su ljudi pričali da ne bi bilo dobro ako se u to kolo uđe. Ive Krmpotić Pićica iz Kuljića se prisjetio: A vile su pričali, ono di je crna livada, da su to vile kolo igrale. Onaj krug trave. (...) Ali kako trava drukcija. Vilino kolo. Trava je bila svugdje zelena, samo se kolo vidi. Drukčija je trava. I kolo je, krug. Al nije krug spojen. (...) Ovako je razmak. To san ja naisa po livadan. I tata pokojni - to je vilsko kolo. (...) I tu je ta vilina ditelina reste. Tu ti reste trava koja ko da je na njoj paučina. Vilina kosa. Milan Krmpotić Zekonja iz Veljuna objasnio je kako su zapravo srne napravile taj krug na travi, da su one igrale.

Pojedini kazivači naglasili su kako se vile moglo vidjeti jedino noću, primjerice, Mile Prpić Popić iz Popića kazao je: A vila se nije moglo vidjet po danu, samo po noći. ${ }^{10}$ Ovaj je kazivač, kao i Zdenka Pavelić Vranićeva iz Pavića, objasnio da su vile živjele u šumama, točnije, u pećinama.

U pojedinim pričama vile su kazivači vezali uz konje. Tako je Anton Prpić Matin iz Veljuna kazao kako su pripovjedali da iđu vile na konjima, dok se Mile Prpić Popić iz Popića prisjetio: Pričali su da su vidili vilu kako konju grivu plete, rep $i$ to. Kazivač je naveo da se objašnjavalo da je konj bio dobar ako su mu vile plele grivu te da se to nije smjelo dirati jer ako se to rasplete da nije dobro za konja, da neće konj bit dobar. No, sam kazivač ne vjeruje u ovu priču, već misli da su konjima griva i rep bili spleteni zbog prašine i blata. Anka Prpić Brunićeva iz Krivoga Puta prisjetila se: Imali smo konje, onda konj po noći, a što ja znan, ja to ne virujen, ja sam to vidila, konj onu grivu, kosu onu, pa mu budi popletena ko pletenica. Il bi

5 Da su vile bile obučene u bjelinu, potvrdili su: Eleonora Prpić Lejina, Veljun; Grgo Prpić Miškec, Gorica; Zdenka Pavelić Vranićeva, Pavići; Ive Krmpotić Pićica, Kuljići; Milan Krmpotić Zekonja, Veljun; Ivan Prpić Kavarica, Lucići; Milka Prpić Markina, Veljun; Tome Špalj Cucin, Krivi Put. Jedino je Milan Prpić Markin iz Veljuna naveo kako su vile imale obučeno nešto sjajno. Milan Krmpotić Zekonja iz Veljuna kazao je da su vile imale obučenu bijelu robu isto ko mlada kad ide na vjenčanje.

6 Dugu kosu kao karakteristiku vila naveli su: Anton Prpić Matin, Veljun; Milan Prpić Popić, Popići (kazao da su vile imale kosu do nogu); Tome Špalj Cucin, Krivi Put; Ivan Prpić Kavarica, Lucići.

7 O tome su govorili: Anton Prpić Matin, Veljun (noge konja ili mule); Anka Vukelić Matićeva, Rupa (noge konja); Zdenka Pavelić Vranićeva i Kata Pavelić Burgijina, Pavići (noge konja); Ive Krmpotić Pićica, Kuljići (muletina noga); Milka Prpić Markina, Veljun (noga mule); Milan Prpić Markin, Veljun (noge konja). Milan Prpić Popić iz Popića naveo je kako su vile imale ljudske noge. Eleonora Prpić Lejina iz Veljuna i Ivan Prpić Kavarica iz Lucića pojašnjavaju kako se noge nisu niti vidjele.

8 Da su vile plesale kolo, naveli su: Anton Prpić Matin, Veljun; Anka Vukelić Matićeva, Rupa; Eleonora Prpić Lejina, Veljun; Luka Krmpotić Brnde, Veljun; Zdenka Pavelić Vranićeva, Pavići; Ive Krmpotić Pićica, Kuljići; Mile Prpić Popić, Popići; Milan Prpić Markin, Veljun; Tome Špalj Cucin, Krivi Put.

9 Kazivači koji su naveli da je na travi bilo moguće vidjeti krug koji je označavao da su tu vile plesale kolo su: Anton Prpić Matin, Veljun; Eleonora Prpić Lejina, Veljun; Luka Krmpotić Brnde, Veljun; Ive Krmpotić Pićica, Kuljići; Milan Prpić Markin, Veljun.

10 O mogućnosti viđenja vila jedino noću govorili su Anka Vukelić Matićeva iz Rupe, Grgo Prpić Miškec iz Gorice i Mile Prpić Popić iz Popića. 
se to on preko noći sam, onda reci noćas su mu vile savile. Milan Prpić Markin iz Veljuna ispričao je iskustvo s vlastitim konjem iz pedesetih godina 20. stoljeća: ... Nego san ja to doživija, ja san ima kobilu mladu. Ona je bila jača od jednoga konja. Ja san je proda tamo u Primorje kad san u Njemačku iša na posa, nije ima kome ostavit. Ona nije bila velika, mala kobilica. A lijepa je bila ko zlato. Njoj svaku noć, ti respleti grivu, počešljaj, sutra si došao, pletenice sve spletene. I one dvi pletenice spojene jedna za drugu, kao rukohvat. Ja ih opet razvali isti dan, počešljaj lipo, odnija baban češalj stari, onaj što glave su prvo one češljale, onaj ritki zubi, pa san ja to rastavlja. Ja sutradan i opet. A ljudima nisan virova dok su mi ljudi rekli da vile, da koga konj spliću vile da jaki, čudo snažan. I da ga one po noći to spliću i jašu na njemu, one mu snagu daju. (...) One su jašile na konju tom. A nisu svakoga konja. Samo odaberu, znadu one koga će izabrat. Iako su mu ljudi govorili da nije smio dirati pletenice, jer je to, kako su rekli, stvar vila, on ih je ipak raspleo jer mu onako spletene, smotano nije bilo lijepo. ${ }^{11}$

Pojedini kazivači povezali su vile sa svojim krajem, kao primjerice Ivan Krmpotić Šoparin iz Šojatskoga Dolca koji navodi sintagmu vila Velebita. Anka Vukelić Matićeva iz Rupe podrobnije je objasnila kako vile žive u šumi te zato se i Velebit pjeva “Oj, ti vilo, vilo Velebita". Tome Špalj Cucin iz Krivoga Puta kazao je kako vile na određen način simboliziraju njihov kraj te su zbog toga i ušle u pjesmu o Velebitu.

Eleonora Prpić Lejina iz Veljuna pojasnila je kako nije svatko mogao vidjeti vile: Netko bi vidio, možemo biti skupa, ja vidit, ti ne. Milka Prpić Markina iz Veljuna ispričala je jedno svoje zanimljivo sjećanje vezano uz pojavu vila: E, babe su pričale da su vidile vile. Ako si vilu vidija, ne smiš reć eno vile. Onda ostaneš, ne moreš izgovarat, veli, da. Jedna je ova, meni je svekrva pričala, tamo čuvala blago i da je rekla di, di, di, ostala tako, dide, eno vile. Onda tako prvo neg bi govorila reci di, di. E, dok je did pogleda, već nema. (...) Govorila je ona, ali prvo tog govora uvik di, di.

\section{VJEŠTICA KO VJEŠTICA}

$\mathrm{V}$ iške ${ }^{12}$ predstavljaju nadnaravna bića o kojima su Krivopućani tijekom ispitivanja najviše pričali te je o vjerovanjima o njihovom postojanju zabilježeno najviše pojedinosti i zanimljivih sjećanja. Iako negativna bića, koja su, prema vjerovanjima, mogla nauditi ljudima i životinjama, priče o njima žive među stanovništvom Krivoga Puta. ${ }^{13}$

Od pojedinih kazivača dobiven je odgovor kako su to u pravilu bile udane žene ${ }^{14}$ ili kako je to objasnio Ivan Prpić Kavarica iz Lucića: A malo su cura vikali, to su sve bile udane. Za njih se vjerovalo kako

11 U Upitnici Etnološkog atlasa Jugoslavije o vilama je zapisano: "Vile su lijepe mlade žene, duge kose koje igraju kolo na livadi i pletu konjima grive" (UEA, IV, 142, Fd 241/478).

12 Svi kazivači koji su govorili o viškama upotrebljavali su ovaj naziv. Uz njega, pojedini su kazivači (Anton Prpić $M a-$ tin, Veljun; Anka Vukelić Matićeva, Rupa; Mile Prpić Popić, Popići; Zdenka Pavelić Vranićeva, Pavićí; Kata Pavelić Burgijina, Pavići; Milka Prpić Markina, Veljun; Branko Tomljanović Ropeta, Krivi Put) upotrebljavali i naziv vještice. Milan Prpić Markin, Veljun; Ivan Krmpotić Šoparin, Šojatski Dolac te Marko i Draga Tomljanović Rilčevi iz Katića su za vrijeme razgovora upotrijebili samo naziv vještica. Eleonora Prpić Lejina upotrijebila je i naziv višketina. Marija Prpić Vinina iz Veljuna jedina je, uz nazive viška i višketina, upotrijebila i naziv coprnje.

13 U Upitnici Etnološkog zavoda Jugoslavije zabilježeni su oskudni podaci o ovim bićima. Na pitanje: "Vjeruje li se ili priča o ženama koje imaju natprirodnu moć da čine zlo (uzimaju mlijeko tuđih krava, prirod s tuđih polja, prave tuču, mraz, uzrokuju sušu, bolest i svađu, jedu ljudima srce, kradu Mjesec ili Danicu ili?) i kako se zovu (vještica, višćica, viška, vešča, veštičina, vešterka, činilica, štriga, štrija, vražarica, brkača, coprnjica, čarovnjica, teta, kuma ili?)?”’ zabilježen je tek odgovor: "Takve žene se zovu vištice", bez dodatnog objašnjenja njihovih natprirodnih moći i navođenja poznatih priča uz njihova djela. Nadalje, na pitanje kako vještica nastaje, zabilježen je odgovor: "Ne znadu kako bi postala. Valjda bi joj to bilo suđeno". Također, za pretvaranje vještice u neko drugo biće, životinju ili stvar zabilježen je odgovor: "Nepoznato im je to." Općenito je o vješticama zapisano, a vezano uz mogućnost njihova prepoznavanja: "To su bile stare žene zla pogleda". O kažnjavanju vještica zabilježen je odgovor "Ne znadu o tomu."; dok je za muškarce koji imaju moć i čine zlo kao i vještice zapisano: "Nisu čuli za to" (UEA, IV, 142, Fd 241/478).

14 O viškama kao udanim ženama govorili su: Anton Prpić Matin, Veljun; Anka Vukelić Matićeva, Rupa; Eleonora Prpić Lejina, Veljun; Mara i Luka Krmpotić Brndini, Veljun; Zdenka Pavelić Vranićeva, Pavići; Ivan Prpić Kavarica, Lucići; Zvonko Pavelić Dujela, Serdari. 
odlaze na Klek, ${ }^{15}$ a rekvizit koji im u tome pomaže je, prema mišljenju pojedinih kazivača, metla. ${ }^{16}$ Pritom je Mile Prpić Popić iz Popića pridodao da viške pršu, imaju krila. Ivan Prpić Kavarica iz Lucića kazao je kako su viške prije svog noćnog odlaska metlom na Klek lojem ili voskom mazale tabane da ih putem ne bode kamenje, dok je Milan Prpić Markin iz Veljuna naveo kako su za tu potrebu imale neku mast te pridodao: E, pa onda viču da "pr, pr, ni od drvo ni o kamen", a ona reče "i u drvo i u kamen". Pa se razbi. Ovu su formulu u pravilnom obliku morale izgovarati prije polaska kako na putu ne bi u nešto udarile.

Sposobnost koju su kazivači najčešće vezali uz viške je krađa mlijeka. ${ }^{17}$ Tako je kazivač iz Krivoga Puta, iako sam ne vjeruje u mogućnost da su viške to činile, potvrdio da je to, kako je kazao, bilo rašireno mišljenje. Pojedini su objasnili kako je ona to činila pomoću uprtice. ${ }^{18}$ Anka Vukelić Matićeva iz Rupe kazala je kako su vikali da može zaustavit mlijeko kravi, bilo je takvih slučajeva, dok su Mara i Luka Krmpotić Brndini iz Veljuna naveli kako je viška vidila kravu i nema mlika. Luka je objasnio: E, imala tu neku moć, to valjda njihova tajna bila, te naveo osobno iskustvo i mišljenje: Izgleda da je moralo nešto djelovat od njih. Ja sam jedanput kravu gonija, kada je ona vidla, nije više mlika u njoj bilo, bilo vrlo malo, jel to tako, nije li, ja isto sam sebi ne vjerujem, nego sumnjaš. Anka Šolić Tutanova iz Šolića iznijela je svoje mišljenje o nastanku priča o viškama: I viška i vjestica. Ona veli muze kravu. Ljudi su tako iznesi bez veze, veli, ona je muzla kravu. Žena jadna, ima dobro kravu, ima mlika, ona je, veli, na uprticu pomuzla. Izmisli iz glave tako i tako reče. Slično razmišljanje izrekao je i Tome Špalj Cucin iz Krivoga Puta: Jednu babu su jadnu, imala je tri krave i sad njih tri će dat više mlika nego ona jedna. Onda ona je imala više toga mlijeka i sira, onda su oni njoj vikali da je ta, bila Franca, o vraga, Vrnca muze na uprticu. Tobože ona gata. (...) Tako, lopovština ljudska. O tome je govorio i Mile Prpić Popić iz Popića: A to su znale ove babe po selu. I onda ako i ne bi bila viška, one nju nazovi viška. Lopovštine. Ovi su kazivači tako postojanje priča o viški vezali ponajprije uz ljudsku zavist ili, kako kaže Tome Špalj, lopovštinu.

Kazivači su nadalje naveli kako su viške mogle ureći ljude ili životinje. ${ }^{19}$ Mara Krmpotić Brndina iz Veljuna kazala je: Ove da su kao vračale, kao da ureče nešto ili blago, da imaju take oči... Kad vidi blago da ga kao ureče, da ne napreduje to poslije blago, take oči da ima, može bit da ne bi ona rado to, je li, ali ako je tako rođeno. Kazivačica je dalje navela kako su ljudi nastojali sakriti blago od pogleda ovih, kako je kazala, vračarka koje su se mogle prepoznati po pogledu: Nekako drukčije, nekako namršteno, nekako čudnovato. Veli ta će vas ureć, blago nemojte joj pokazivat kad kupite ili nešta. Zbog tog se, kako je kazala kazivačica,

15 O Kleku kao mjestu na koje su dolazile viške govorili su: Eleonora Prpić Lejina, Veljun; Ivan Krmpotić Šoparin, Šojatski Dolac; Kata Pavelić Burgijina, Pavići; Zdenka Pavelić Vranićeva, Pavići; Milan Krmpotić Zekonja, Veljun; Ive Krmpotić Pićica, Kuljići; Mile Prpić Popić, Popići; Ivan Prpić Kavarica, Lucići; Milka Prpić Markina, Veljun; Milan Prpić Markin, Veljun; Marija Prpić Vinina, Veljun.

16 Metlu kao rekvizit spomenuli su: Eleonora Prpić Lejina, Veljun; Kata Pavelić Burgijina, Pavići; Ive Krmpotić Pićica, Kuljići; Mile Prpić Popić, Popići; Ivan Prpić Kavarica, Lucići; Milka Prpić Markina, Veljun; Milan Prpić Markin, Veljun; Marija Prpić Vinina, Veljun.

17 O sposobnosti vještica da kradu mlijeko govorili su: Anton Prpić Matin, Veljun; Anka Vukelić Matićeva, Rupa; Eleonora Prpić Lejina, Veljun; Mile Prpić Popić, Popići; Mara i Luka Krmpotić Brndini, Veljun; Zdenka Pavelić Vranićeva, Pavići; Milan Krmpotić Zekonja, Veljun; Ive Krmpotić Pićica, Kuljići; Anka Šolić Tutanova, Šolići; Branko Tomljanović Ropeta, Krivi Put; Grgo Prpić Miškec, Gorica; Stjepan Prpić Stipina, Gorica; Francika Šojat Babićeva, Šojatski Dolac; Ivan Pavelić Jandra, Serdari; Marija Prpić Vinina, Veljun; Marko Tomljanović Rilac, Katići; Nada Prpić Terezina, Krivi Put; Mirko Prpić Cungo, Krivi Put; Anka Prpić Brunićeva, Krivi Put.

18 O muženju preko uprtice govorili su: Anton Prpić Matin, Veljun; Mile Prpić Popić, Popići; Mara i Luka Krmpotić Brndini, Veljun; Zdenka Pavelić Vranićeva, Pavići; Milan Krmpotić Zekonja, Veljun; Anka Šolić Tutanova, Šolići; Branko Tomljanović Ropeta, Krivi Put; Stjepan Prpić Stipina, Gorica; Eleonora Prpić Lejina, Veljun; Ivan Pavelić Jandra, Serdari; Marija Prpić Vinina, Veljun; Marko Tomljanović Rilac, Katići; Nada Prpić Terezina, Krivi Put; Mirko Prpić Cungo, Krivi Put.

19 O tome su govorili: Mara i Luka Krmpotić Brndini, Veljun; Ivan Krmpotić Šoparin, Šojatski Dolac (ljude i blago), Zdenka Pavelić Vranićeva i Kata Pavelić Burgijina, Pavići (ljude i blago); Ive Krmpotić Pićica, Kuljićí; Mile Prpić Popić, Popići (sjeća se jedne koja je urekla dijete); Milka i Milan Prpić (ljude i blago) Markinovi, Veljun; Zlata Tomljanović Pešina, Krivi Put; Branko Tomljanović Ropeta, Krivi Put; Grgo Prpić Miškec, Gorica (ljudi i blago). Anka Prpić Brunićeva iz Krivoga Puta upotrijebila je izraz plaši ljude, nešto baca. 
ružnog pogleda, niti čovjek, prema riječima njenog supruga Luke, ne bi osjećao najbolje. Grgo Prpić Miškec iz Gorice kazao je da se odma kao izgubi. Zlata Tomljanović Pešina iz Krivoga Puta je na pitanje kako je osoba znala da ju je netko urekao odgovorila: A pa šta ja znan, ja ne znan, kako bi rekla, ako bi joj se nešto dogodilo, na primer nešto nevaljano, vidiš je, kaže, onda je kuni, onda reci, vidi urekla me, kaže, prokleta viščetina. Kazivačica je dalje navela kako su postojale stare žene koje su znale odgovoriti urok.

U Veljunu je zabilježena sljedeća priča ${ }^{20}$ vezana uz četrdesete godine 20. stoljeća: Bila je ode jedna, došla iz Brloga, od Otočca, ode se bila udala. I moja sestra, od mene je starija bila 3 godine. Tu je došla od nje. A ona imala jednog od muža brata, to je bija, mi zvali patuljak, što je mali bija, nedorasli, stari je već bija. Doša je tu u kuću, pita mlika, nosi jednu flašicu dva decilitra, da mu neka majka da mlika. Što ćešs dva decilitra. A ćaća je bija vani ko ja ovako. Stari uđe u kuću, majka nasula mlika i on ne da začepit nego svojih dole hlača otpara komad i metni u onu flašicu. A stari vidija što se dela, on bočicu pras, razbi. On proša kucii, kaza i, što misliš, sestra moja ošla tu doli po vodu i glava joj se naopako okrenula, lice ošlo nazad. Što će, ćaća ka ćaća, majka k njoj, zna si da prasica to napravila i onda dode da ditetu postriže nokte i u vodi popit nokte svoje. I glava se vratila. Onda je otišla, odnija je vrag tamo, u Brlog, zavadila curu i dečka, ovaj dečko je dozna što je stvorija, srusi je, probode kolac u zemlju i ostavi je onako. I tad je vrag odnija. ${ }^{21}$

Ljudi su, prema riječima pojedinih kazivača, nastojali izbjeći susret $s$ osobama za koje se pričalo da im mogu nauditi. Tako je, primjerice, zabilježeno ovo kazivanje: Nisu ih ljudi baš rado imali, pričali su s njima, ali nije nitko želio imati posla s njima. (...) Kao nemoj s njon imat posla, ona to more nešto nabacit, nemojs njon lipo ni ružno, zaobidi je i tako, nemoj je pustit ni u kuću da ti nešto dođe pa da uzme. Također, jedno od vjerovanja je bilo da nije dobro da viška prijeđe preko puta, o čemu govori priča: Kad bi god ona priko išla, ljudi su joj se uklanjali, nisu mogli ništa, nego ako je ona prišla preko puta, vraćali se nazad, to nije dobro kad bi prišla preko puta. Slična priča o ženi za koju se vjerovalo da nije dobro da prijeđe preko puta kaže: $A k o$ ženska ide, ja idem sad s konjom s kolima, $i$ ako mi prede preko puta, e, onda mi se bolje vratit nazad nego da idem dalje, svašta se moglo dogodit. Ako ona nosi što u ruci, ako ide i nosi praznu kantu. Ja sam jednom isto iša i to dva puta, jednom mi prišla priko puta, ja iša kovat konja u kovačnicu, izašo na glavnu cestu i policija, hop! I kazni me trista hiljada što nisam imo zvono na konju. I onda drugi put isto mi je prošla, i onda sam je po ušima, po glavi, pridi nazad! Onda je prišla, onda sam proša i dobro. A ista jedna gore na Veljunu, ta je umrla, tri puta sam voz sjena navaga i prevalit, i odma sam osjetio da je ona prišla preko puta mi, i konji neće uzbrdo da voze, onda morate preokrenut, naopako, na drugu stranu, e, onda ne može više mokrit. Kazivač je ovoj priči pridodao da još punu kantu ako nosi dobro, al ako prazna kanta, onda će nešto napravit. Za zaštitu od njenog utjecaja bilo je potrebno reći: Pomozi, Bože. Kazivač to jednom nije učinio i kobila nije htjela ni pet vreća krumpira prenijeti jer je ova žena bila prisutna, a prije toga je, prema njegovim riječima, bez problema ponijela dvadeset i pet.

Tek su pojedini kazivači naveli kako su viške imale i sposobnost pretvaranja. Tako je Luka Krmpotić Brnde iz Veljuna kazao kako su se mogle pretvoriti u leptire, Zdenka Pavelić Vranićeva iz Pavića navela je da se mogu pretvoriti u više toga, no najčešće u mačketinu, Milka Prpić Markina iz Veljuna kazala je da se viška mogla pretvoriti u gujinu, muvu, svašta, a njezin suprug Milan misli kako su mogle postati žabe, zmije i kokoši. Međutim, nitko od kazivača nije objasnio kako su one to uspijevale niti jesu li time nešto posebno postizale.

Pojedini kazivači naveli su kako je svećenik, dok su drugi ljudi sumnjali i pričali, ${ }^{22}$ jedini mogao vidjeti vještice i sa sigurnošću znati koja je žena viška. Tako je Anton Prpić Matin iz Veljuna pojasnio: Stari su ljudi pripovidali da vještice te, da pop može samo svaku vidit u crkvi kad je, kad diže Sveti sakrament, onda

20 Priču su odvojeno ispričala dvojica kazivača.

21 Marija Prpić Vinina iz Veljuna kazala je kako coprnje mogu čovjeku okrenuti glavu.

22 Marija Prpić Vinina iz Veljuna jedina je spomenula kako su coprnje znale obući jednu šlapu i jedan opanak te se po tome znalo koja je viška. Kako je kazivačica jedina navela ovu svima vidljivu pojedinost po kojoj bi se viška izdvajala, podatak treba uzeti s oprezom. 
da vidi svaku, da ima ko sito, rešeto na glavi. Ive Krmpotić Pićica iz Kuljića kazao je kako je njemu djed tumačio da svećenik viške vidi kad diže Sveto tilo. Milan Prpić Markin iz Veljuna također je ispričao kako je svećenik u crkvi vidio viške, no zbog toga što su one zaštićene nije smio kazati koje su: A one su zaštićene jer su one Isusa zaštitile, sakrile ga kad su ga tjerali oni Židovi. Onda u crkvi pop ih vidi, ali ne smije odat. (...) A on ih vidi sam, a kako ih može vidit, ja ne znan. Također, svatko je mogao na božićnu polnoćku u crkvu donijeti tronožac te i sam vidjeti viške, no također poput svećenika nije to smio nikome reći jer su vještice Isusa zaštitile kad je bježao sa svojom majkom: Onda su imalo tronožac stolac, na tri noge ovako, od drveta istesano lipo, to su stolčić nosili u crkvu, to su babe prvo pričale, onda se popni na taj stolčić i vidi svaku vješticu koja je u crkvi. Da ima sito na glavi. (...) Na ponoćki na Božić. Jedan je od kazivača naveo kako mu je njegov djed savjetovao: Kaže, uzmi pređu i oko crkve prođi i sveži na vratin na ulazu. Svi će izać van, one ce ostat u crkvi.

Vezano uz odnos svećenika i viški zabilježena je i ova priča: Baš je to bilo tu u Krivom Putu, u crkvi, ja se sićam tog popa starog. A jednu ženu, tu iz ove kuće tu, sad je ta kuća srušena, ona je bila vještica. To mliko da je ona od krave muzla $i$ tako. Tude krave odu na pašu, kod njene kuće bi urlikale, bugaru krave, $i$ onda da je to mlijeko muzla i kuvala i delala taj putar, onda on njoj naručija neka njemu donese taj putar, da će on kupiti. I ona kad je donila, onda je on kleka na kolina, u stanu svom, a on je molija, uze knjigu i molija. Kako god da moli, taj putar iskaka iz te kante, da je iša van, ostalo je a jedno pola litre možda, da je ostalo putra u kanti, onda on njoj reka: ovo ću ti platiti, a ovo je otišlo! I nikad to nemoj više delati sirotinji!

Jedna se kazivačica prisjetila zgode od prije četrdesetak godina sa ženom koju su zvali viška, a koja je u dva navrata, prema njenom mišljenju, pokazala svoje neobične sposobnosti na njenom suprugu. Jednom je došla u njihovu kuću uzeti sijeno i za vrijeme dok je bila u kući, njezin suprug je nepomično ležao na otomanu, ${ }^{23}$ dok je drugi put kad je došla nešto pozajmiti u njihovu kuću, pao s tavana, $s$ oko dva do tri metra visine na glavu. Zanimljivosti koje se također vežu uz tu ženu jesu i da joj je nadimak bio Okana, što je kazivačica objasnila riječima: Valjda je imala oči take, pogled, te da su ljudi nalazili klupka vune koja su povezivali s njom. Kazivačica je također pridodala da je i njena majka bila takva te da se to vjerojatno nasljeđivalo.

Poput zgode o Okani koja je dolazila po nešto u susjedne kuće, zabilježena je i priča po kojoj su viške i drugdje posuđivale od svojih suseljana, primjerice, soli i kvas od kiselog mlijeka: Uvijek su nešto tražile, posudivale u selu, uvijek im nešto falilo. I uvik su tražile po raskrižjim, tražile, da su išle i uvik su nekakve kamenčiće bacale.

Mile Prpić Popić iz Popića prisjetio se kako su vještice bile poznate po tome što su krale, opisao ih je obučene u isparanu haljinu i umotane u crni rubac, koji im je otkrivao samo oči. Ovaj kazivač jedini je donio objašnjenje o postanku vještica: A vještica postaje od čovika, od žene, ako je žena vražja, ona se pritvori u vješticu. Ivan Prpić Kavarica iz Lucića naveo je kako se višketinama nazivalo žene koje su se izdvajale svojim ponašanjem: A bilo je takvi koji smo mi vikali, a da li to bilo istinito, da li nije bilo istinito, ali to smo mi vikali, ako je bila malo vražja ili sebična ili kako bi ti ja to reka, reci to ti je višketina.

Luka Krmpotić Brnde iz Veljuna ispričao je kako su ljudi mogli prepoznati koja je žena viška: Prije su ognjišta bila, onda uz ognjište lezi, žari željezo, ima je klišta i kad je došla, on je manio s onim željezom, uvati je malo po nosu, onda su po tom poznali da je viška. Tako je to bilo, to sam čuja, to je moj ćaća pričo.

U Veljunu je zabilježeno sjećanje na Maru Krmpotić Sokolušu koja je ostavljala lug na križanjima: Ona ti je uvik kad su bile te kvatre $i$ mine, uvik je nekog vraga sipala. Na taj se lug koji se nalazio na raskrižjima nije smjelo nagaziti. Za ovu se ženu također pričalo da muze na uprticu te je jedna krava uvijek bježala na kantun kuće u kojoj je ona živjela. Zabilježeno je kako je ona uvik nekog vraga kopala $i$ sakrivala te kako je pod svojim pragom imala bočicu mlijeka. ${ }^{24}$

23 Marija Prpić Vinina iz Veljuna kratko je napomenula kako su coprnje mogle učiniti da se čovjek ne more dizat.

24 Nije zabilježeno objašnjenje. 
Bića koja kazivači povezuju, a većinom i poistovjećuju s vješticama su more. ${ }^{25}$ Zdenka Pavelić Vranićeva iz Pavića kazala je: Sad mi zovemo viška i mora. Netko reče viška, netko mora rě́e, da to je isto, e. Jedino su Mile Prpić Popić iz Popića i Ive Krmpotić Pićica iz Kuljića objasnili razliku između mora i viški: Kad se uda, onda je viška, a kad je mora, onda je cura. Normalno. Tako se vikalo. ${ }^{26}$ Milan Krmpotić Zekonja iz Veljuna i Ive Krmpotić Pićica iz Kuljića kazali su kako su se viške i more rađale od majki koje su također imale takve sposobnosti: To ti nastaje tradicija, majka i ćer. (...) Prinaša se s koljena na koljeno. More su bića koja ne daju spavati, ${ }^{27}$ gnjave ${ }^{28}$ more, ${ }^{29}$ duše, dave. ${ }^{30}$ Kao zaštitu od mora pojedini su kazivači spomenuli češnjak, ${ }^{31}$ odnosno luk, ${ }^{32}$ kojima bi se namazala prsa, odnosno malo luka bi se trebalo pojesti. ${ }^{33}$ Eleonora Prpić Lejina iz Veljuna kazala je kako su žene stavljale ditetu pod glavu križ, Spasitelja i tri glavice češnjaka. ${ }^{34}$ Ive Krmpotić Pićica iz Kuljića naveo je sljedeće sredstvo zaštite od mora: Kajiš muški skini i privuci ga priko vrata di spavaju. Onda ne bi dolazile.

Jedan od kazivača donio je vlastito iskustvo s morom iz vremena sredine 20. stoljeća: Zajaši na čovika pa ga davi, uiti ga pa ga cica po noći, ovake mu prsi nacica. I mene su bile nacicale. Kako je znao koja mu je žena to napravila, odlučio joj je preko njenog unuka zaprijetiti te ga je nakon toga prestala cicati. Kata Pavelić Burgijina iz Pavića ispričala je kako je njenog oca često mučila mora: To zna moj tata, njega je često ta mora mučila dok je spava, po noći. Onda on je vidija, kad se probudija, da je vidija da ima sito na glavi. $D a$, ta vještica. Pojedini kazivači naglasili su kako su more mučile prvenstveno djecu: Kad malo dite bilo, pa mu malo nateci prsa ovako. Veli, joj, mora ga pocicala. Malo mu nateci. ${ }^{35}$

Kazivači su naveli i pojedine postupke kojima se moglo zaštititi od negativnih bića u čije su sposobnosti ljudi vjerovali. Tako uz već spomenutu zaštitu protiv mora, pojedini kazivači spominju kako se blagu, prvenstveno kravama na koje su viške krađom mlijeka i imale utjecaj, vezala pređa, ${ }^{36}$ odnosno crvene vrpce. ${ }^{37}$ Milan Prpić Markin iz Veljuna ispričao je kako su se vezale trake: A više boja, jednu kitu veliku ko ova flaša, crveni, bijeli, plavi, svakakvi, a to se višalo na jednog vola i konja, koji je bolji, na dešnjaka se recimo

25 O morama su govorili: Anka Vukelić Matićeva, Rupa; Mara i Luka Krmpotić Brndini, Veljun; Grgo Prpić Miškec, Gorica; Zdenka Pavelić Vranićeva, Pavići; Kata Pavelić Burgijina, Pavići; Ive Krmpotić Pićica, Kuljići; Mile Prpić Popić, Popići; Ivan Prpić Kavarica, Lucići; Milka i Milan Prpić Markinovi, Veljun; Zlata Tomljanović Pešina, Krivi Put; Anka Šolić Tutanova, Šolići; Tome Špalj Cucin, Krivi Put; Eleonora Prpić Lejina, Veljun. Svi kazivači osim Mare i Luke Krmpotić Brndinih iz Veljuna, Ive Krmpotić Pićice iz Kuljića i Anke Šolić Tutanove iz Šolića izričito izjednačuju more i viške. U Upitnici Etnološkog atlasa Jugoslavije zabilježeno je da se biće koje je ljude i životinje mučilo, tištilo, gušilo u snu, sisalo im krv ili prsa nazivalo mora, no nisu navedeni podrobniji podaci o njenim postupcima ("Ne znadu kako onda to radi ali vjerojatno to radi njen duh."), tek je navedeno objašnjenje: "Mora je neka stara i lajava žena u selu". Uz to, još je jedino naveden postupak za zaštitu od more: "Maloj djeci treba namazati prsa češnjakom a blagu privezati neku crvenu vrpcu” (UEA, IV, 141, Fd 241/478).

26 Riječi Ive Krmpotića Pićice iz Kuljića.

27 Riječi Anke Vukelić Matićeve iz Rupe.

28 Mara i Luka Krmpotić Brndini iz Veljuna.

29 Grgo Prpić Miškec iz Gorice.

30 Ive Krmpotić Pićica iz Kuljića.

31 Kata Pavelić Burgijina iz Pavića.

32 Mara i Luka Krmpotić Brndini, Veljun; Ive Krmpotić Pićica, Kuljići.

33 Milka Prpić Markina iz Veljuna vjeruje da je luk svojim mirisom tjerao vještice, tj. more te ga se trebalo malo pojesti.

34 Kazivačici nije poznato značenje češnjaka.

35 O tome su govorili: Ive Krmpotić Pićica, Kuljići; Ivan Prpić Kavarica, Lucići; Anka Šolić Tutanova, Šolići.

36 Mara i Luka Krmpotić Brndini iz Veljuna govorili su o pređi različitih boja koja se vezala kravi na rep. Eleonora Prpić Lejina iz Veljuna upotrijebila je naziv preja te također kazala da se raznobojna preja stavljala kravama na rep.

37 O crvenoj vrpci govorili su Branko Tomljanović Ropeta iz Krivoga Puta i Mile Prpić Popić iz Popića. Crvene trake spomenuli su Ive Krmpotić Pićica iz Kuljića i Milan Krmpotić Zekonja iz Veljuna. Ive Krmpotić Pićica kazao je kako se to radilo u kvatrama, ali ne zna zbog čega. 
višalo veliko zvono $i$ kita, a kravi na rep i oko vrata. Tako da ista coprnja, ona koje muze kravu, da prvo pogleda u rep u kravu da ne vidi vime. Tako su žene odbijale to. (...) E tako i na mlado telešce. A stajalo naročito prid telivo i posli teliva kravi i dok je tele malo. (...) Na rep i na zvonce. I oko rogova vezale babe, svakako. A branile su. Muzle su. I moje su krave muzle. Zlata Tomljanović Pešina iz Krivoga Puta prisjetila se kako su se crvene krpe vezale posebno kravama koje su imale veliko vime: Jesu, kravama na rep. Ako bi vidili veliko vime, onda su znale stare babe svezat crvene krpe. Crvenu krpu, onda kad bi vidili veliko vime u krave, ta da puno mlika, može je ureć, crvenu krpu su vezali. Jedan od kazivača prisjetio se kako su u Škopcima u jednoj kući kravama na rep vezali božićne kosti, kosti od mesa koje se blagovalo na Božić, no nije znao objašnjenje toga postupka. Milan Prpić Markin iz Veljuna kazao je kako se radi odgona vještica bršljan koji se stavljao oko božićnog kruha zabijao za grede u štali. Ivan Prpić Kavarica iz Lucića naveo je kako se grančica koja je blagoslovljena u crkvi na Cvjetnicu zaticala u štalu: To su radili da ne bi došla viška. Milka Prpić Markina iz Veljuna kazala je da se takvom blagoslovljenom drinovom šibom blago išibalo da ga ne more niko ureć $i$ tako, to su babe vikale. Njezin suprug Milan prisjetio se kako večer prije Jurjeva babe u šprahet metni jedni staru cipelu da gori, tobož vješticama za večeru. Ona smrdi ka vrag.

\section{PRITVORI SE U VUKODLAKA}

$\mathrm{V}$ jerovanje u postojanje vampira i vukodlaka potvrdili su pojedini kazivači. ${ }^{38}$ Anton Prpić Matin iz Veljuna kazao je kako su ljudi pripovijedali da je bilo vampira ta kako su oni stariji od vraga, jači, veći, no nije znao objasniti što je vampir mogao učiniti ljudima.

Mile Prpić Popić iz Popića prisjetio se izgleda vukodlaka: To je ima dugačku dlaku, vukodlak, da je sličan vuku i veliku dlaku ima. (...) A vuk je bio, vuk. A zna se i čovik da bude vukodlak i njega su zvali vukodlak isto, sav čupav, velika kosa na njemu, vuna, gol, i to su zvali vukodlak. (...) Ko pračovjek neki, ko će znat što je bio. Ovaj kazivač ispričao je kako je u njihov kraj vukodlak jednom, kad je on bio dijete, došao iz Primorja i narod ga se jako plašio. Govorilo se da je došao iz pustinje i da živi tri stotine godina. Kata Pavelić Burgijina iz Pavića ovako je opisala vukodlaka: Ima i rogove i dlaku, vrag, pripovidali su. Znali su to pripovidat kad bi se dica strašila. (...) Vukodlak čovika okreće, okrene ga, ako na Božju, on okrene na vražju, on okreće na svoju. (...) Ima moć u sebi. Na primjer, veli vidio je kako vodi kola, veli, čovik, crvena kapica, kao noge za kotačem i konji, $i$ to praši vukodlak.

Ive Krmpotić Pićica iz Kuljića kazao je da su vukodlacima, prema pričama njegova djeda, nazivali griješne ljude koji su se pojavljivali nakon svoje smrti i nisu davali ljudima mira.

U Veljunu je zabilježena ova priča: A to su ljudi vikali da se čovjek pritvori u vukodlaka. Kao vrag runjav, orunjavi sav kao vuk. Zato ga zovu vukodlak. Da ga je Bog kaznija što je vrag bija na zemlji. E, kad vrag umre, onda leti, ne da narodu mira. Prema mišljenju kazivača vampir i vukodlak su dva naziva za isto biće: $A$ to su ljudi rekli, a to sve jedno isto, on se povampirija, stvorija se u vukodlaka. Iako su babe rekle da se mrtvac može povampiriti ako preko njega prilikom čuvarine prijeđe mačka, kazivač je iznio mišljenje da se to ipak događalo ako on bija lopov, mrzija čovika, čoviku zlo pravija, onda ga Bog kaznija. Sve do prije desetak godina ovaj je kazivač obavezno jednu večer između blagdana Velike i Male Gospe slušao kako na obližnjem brdu zvoni zvono te kako dva vampira ruše kamenje.

Zabilježeno je i kako su se ponašanje i izgled ljudi povezivali s vukodlacima. Tako se, primjerice, za ružnog muškarca reklo da je kao vukodlak, odnosno: Kad je neko loš, baš si ka neki vukodlak, kao da nije od svetinje, nego kao da je vukodlak, e, bašsi ko neki vukodlak.

38 Anton Prpić Matin, Veljun; Mile Prpić Popić, Popići; Grgo Prpić Miškec, Gorica; Kata Pavelić Burgijina, Pavići; Tome Špalj Cucin, Krivi Put; Ive Krmpotić Pićica, Kuljići; Milan Prpić Markin, Veljun. U Upitnici Etnološkog atlasa Jugoslavije uz sva je pitanja vezana uz vukodlaka i vampira zabilježen odgovor: "Nepoznato je takvo biće" (UEA, IV, 141, Fd 241/478). 


\section{VELI - TO JE MRAČNJAK}

$\mathrm{O}$ postojanju mračnjaka zabilježene su različite priče. Nekoliko je kazivača iznijelo vlastita iskustva susreta s, kako su vjerovali, mračnjakom, dok su pojedini pokušali objasniti kako je moglo doći do vjerovanja u postojanje ovog bića. ${ }^{39}$

Tako je Anton Prpić Matin iz Veljuna objasnio da se mračnjakom zvalo biće koje noću ide u jednon ko stablu. Kazivač je slušao ovakve priča kad je bio dijete - ljudi pripovidali, sastali se. Nije znao pobliže što je mračnjak radio. Slično je i Grgo Prpić Miškec iz Gorice kazao da se mračnjak prikazuje noću.

Osobno iskustvo susreta s mračnjakom otkriva sljedeća zabilježena priča: Ja mislim da sam mračnjaka možda baš doživila i ja! Ja mislim da je to morao biti mračnjak. Kada sam bila mlada cura, s svojih možda 18 godina, još jedna cura iz sela, jedna starija, koja se nikad nije oženila. Mi smo bili u selu Francikovcu, to jedno selo koje dijeli nas. Naveče smo došle kasno iz Francikovca kod nas u kuću, i sad, ja i ova starija pratimo ovu mladu do njezine kuće, (...) i kroz šumicu nekakvu, treba ići okolo pa nije baš. A, govorili su ljudi, prije, da u tom gaju straši. (...) Stoji žena, možda jedno deset metri visoka, ne vidiš joj lice, samo vidiš da je ženska. Crna halja, ni jedan brokat, ni jedna svila se nije tako sjajila. Mi se krivile, derale se. (...) To sam vidjela, a što je bilo to. Sutradan smo išli vidjet, do tog stabla, ali nikakvih tragova nije bilo ujutro. To se desilo uveče oko ponoći, pola jedan. (...) Ženska u crnom, viša od deset metri u visinu, a u širinu oko dva do tri metra. Samo je stajala. Mi smo plakale i vriskom pobjegle kući (...) Ja mislim da je to bio mračnjak, sad, da li je ili nije, ja ne znam. Nitko nikad nije objasnio. Netko je rekao da smo izmislili, netko je vjerovao.

Jedan je kazivač iznio priču svog djeda koji je ovako opisivao mračnjaka: To su vikali da ide ko stog sena, da se zemlja ne dodira. To isto mi did tumačija. (...) Veliko, kao šuma neka. To ja nisan vidija. (...) On je, veli, od zemlje odmaknut puno i to, veli, samo ide. (...) To ti je on meni tumačija, priča te, priča kako straši uveče.

Ivan Prpić Kavarica iz Lucića mračnjaka je opisao kao velikog čovjeka, dva puta većeg od ostalih ljudi, koji se noću mogao vidjeti po šumama ili na putevima, te pridodao kako ništa nije radio ljudima. Milan Prpić Markin iz Veljuna kazao je kako su stari ljudi pričali da je mračnjak visok i crn ko vrag. Zlata Tomljanović Pešina iz Krivoga Puta naglasila je kako mračnjak noću straši i plaši.

Kazivanje Mile Prpića Popića iz Popića izdvaja se po tome što on kaže da su mračnjacima nazivali ljude koji se noću nisu ničega bojali: Ljudi koji su išli po noći, ne vidi se ništa, i on ide po šumi, ne plaši se nikoga, onda su ga zvali mračnjak. Koji se ne boji ni medvjeda ni vuka, ni ničega, cijelu noć može hodat u šumi, ničega se ne plaši. Isto je mišljenje potvrdio i Jure Tomljanović Ban iz Šolića.

Anka Šolić Tutanova iz Šolića navela je dio svog iskustva kojim je željela objasniti kako nastaju priča o mračnjacima te kako se neke pojave u mraku mogu pogrešno protumačiti: Sve vragove. I mračnjake. Vidit ćete kako se dođe do tog mračnjaka. Ja san živila gor, mi smo kuću pravili u Krivon Putu, a ode san vrta imala. (...) I sad ja, tu veče, već se smrklo, ja velin, odi tetka otprati me malo. I mi došle u te Matiće tu gore, sad ona veli, neka ide s nami. I sad idemo nas troje. I sad mi idemo, i vidi cigareta i zasja se. Veli - to je mračnjak. I sad mi stali. A to su dvoje mladi sjedili (...), nji dvoje su ašikovali.

Slično je kazao i Tome Špalj Cucin iz Krivoga Puta; po njemu mračnjakom bi ljudi nazivali svoju sjenu: Kad je ono lijepo mjesečina, vi idete, tamo iznad brda, reko bi da čovjek ide, onaj odsjen baca, pa je narod onda, deset metari visok. (...) Velik čovjek. Svoj odsjen.

\section{KAŽU ZA VRIME, PROGNOZERI}

Dojedini kazivači sjećaju se priča o vrimenjacima..$^{40}$ Tako je Mile Prpić Popić iz Popića objasnio: To su bili oni što danas kažu za vrime, prognozeri. Vrimenjak je čovik koji je to znao, da, on je prognozira kad će kiša bit, kad će sunce bit, i on je sve to ko što ovi danas priko radija govore. Da, to je čovik iz sela bio. (...) Te su

39 O mračnjaku su govorili: Anton Prpić Matin, Veljun; Eleonora Prpić Lejina, Veljun; Mile Prpić Popić, Popići; Grgo Prpić Miškec, Gorica; Ive Krmpotić Pićica, Kuljići; Ivan Prpić Kavarica, Lucići; Zlata Tomljanović Pešina, Krivi Put; Milan Prpić Markin, Veljun; Anka Šolić Tutanova, Šolići; Tome Špalj Cucin, Krivi Put.

40 Zabilježeno je i kazivanje kako su pojedini ljudi po zvijezdama, izgledu neba prognozirali vrijeme, ali uz njih nije vezan naziv vrimenjaci. 
ljude zvali vrimenjak, kaže, on će vam kazati. (...) On, vrimenjak, on je kaziva kad će kiša, kad će vrime, kad će snig, on je zna kolko će duga zima bit, oće li biti topla, hladna. To je znao po prasetu. Kad se prase zakolje, on je zna po onoj slezeni, on je onda zna ako je vamo debela, biti će zima na kraju, ako je tanka, bit će počinje ujesen, ako je ona slezena vamo debela $i$ amo u sredini tanka, $i$ kaže u sredini, u sred zime će bit jaka zima. Tako on govorio, $i$ točno bilo. Prema riječima ovog kazivača, vrimenjak je mogao i sam utjecati na vrijeme: Ako će doći ova tuća, krupa što je padala, on nosi stolac van i okreni naopako, da gori noge, ko rogovi. A većinom su bili oni stolci na tri noge, na tri štapa. I sad, kad bi on vidija da će vrime on ga okrene ovako, prid kuću. I kiša stane. E, taj bi mu stolac bija ko pomoć. (...) E, kiše je on dozivo. Kako, ja to ne znam. Iša je u šumu i doziva.

Ivan Krmpotić Šoparin iz Šojatskoga Dolca također je spomenuo ljude koji su mogli predvidjeti kakvo će biti vrijeme, premda nije donio sve detalje na koji su način oni to činili: $A$, bilo je i takvih, ja ih se dobro sjećam, dosta ih je bilo. Vrimenjaci, neko ih je zva misećari, dosta ih je bilo tamo di sam se ja rodio, u Veljunu. Oni su obično izlazili van uveče, u zapadu sunca, i promatrali su oblake, i ako je bila, znali smo tu uzrečicu reć: "Ako je crvena veče, dobro jutro reče", znači da će sutra biti dobar dan, ako onako crvenkasto bude. Ako su bile one, crne guste, po oblacima, i tako su ti ljudi pogadali vrijeme.

\section{BAKA KOJA JE UMRLA SJEDI GORE}

$\mathrm{T}^{\mathrm{i}}$ ijekom ispitivanja vjerovanja u nadnaravna bića zabilježeno je i nekoliko priča koje su kazivači vezali uz mrtve osobe koje se pojavljuju nakon smrti.

Tako je jedan kazivač ispričao svoj doživljaj susreta s ubijenim čovjekom iz susjednog sela, iz vremena nakon Drugoga svjetskog rata: To bi ti moga reć istinito ja i baš je žena. Mi smo sjedili kod njezine kuće na prozoru, tu ti je jedan čovik je poginija, zapravo ne jedan neg dva poginula. I sad smo mi sjedili $i$ tako zabavljali se. I jedanput se stvorio taj čovjek. Ne samo da vidilo je jedno, nego smo vidili ga obadvoje, doša je na šternu i napi se vode i nesta. Mrtvac je izgledao poput tog čovjeka dok je bio živ, na njemu nije bila vidljiva nikakva rana.

Jedna priča govori o susretu s djevojčicom od desetak godina, obučenom u bjelinu. Slično je i kazivanje o susretu s mladom djevojkom u bjelini i okićenom pavenkom, koja je pjevala tankin glason. Njeno se pojavljivanje povezivalo sa smrću mlade djevojke u susjednom selu koja se, kao što je bio običaj kod mladih djevojaka, pokopala s pavenkom.

Zabilježena je i zgoda koju je ispričao jedan momak koji je na putu od djevojke iz Alana prolazio pokraj groblja: Onda je iša pored groblja, a najedanput kaže on prolazi, a ide, kaže, kočija sa dva gospodina sa cilindrin na glavi i konji idu, a najedanput odoše sve uzbrdo. A tu je baš borovina i da su ošli u tu borovinu. Da je on to vidija, on to priča, a dal je to istina. Kazivačica je pridodala kako se o mrtvim osobama puno pričalo: Da straši, da plaši. Vidija san toga tu, taj plaši, vidija san toga tu, taj plaši. Jako puno.

Jedna je kazivačica iznijela priču iz svoje obitelji, pridodavši kako ona sama nije imala takvo iskustvo: Moja baka bi rekla njegovoj ujni, koja za ujca bila udata, idi gore na štalu dat blagu sijeno. I ona govori da je baba neka druga ispružila noge, što je umrla. Noge kud ova mora proć. Baka koja je umrla sjedi gore kud ova mora proć na tavan. (...) Ja san to radila poslije njih, ja nisan nikad vidla te babe ni njezine noge.

Ive Krmpotić Pićica iz Kuljića kazao je kako su ljudi znali uz mjesto nečije smrti vezivati i pojavu svijeće: I onda veli, tamo di je umrlo, tamo san, veli vidio svijeću. A to su ti ljudi pričali. Ono kad priča one svoje proživljaje.

Branko Tomljanović Ropeta iz Krivoga Puta donio je objašnjenje kako su mogle nastati ovakve priče o mrtvacima: A to san ja doživija na svoje... Tako su pričali kad se ide prema crkvi, tamo je križ, na vrh iz Krivog Puta je križ. Ja san iša od nje. Jugo, kiša pada, jugo, ja iden u dva sata poslije ponoći, a tamo su vikali - slaže drva, prilaže drva po noći, vozi lance, kopa. A ja tu moran proć, amo kroz polje mi je blato. Šuškavac. Kad ja doša blizu, čujen ja lanac, meni kosa pod kapon, ja dva kamena. Ja bliže. Vuče lance, kopa, gotovo. Kad ja malo dalje, vjetar nosi maglu. A tabla Krivi Put je bila pričvršćena i tablu jedan čaval nije drža. (smijeh) 
Da ja nisan proša, ja bi mislija da kopa, da vuče lance. A bili uvjereni, ljudi su slušali vozi lance, slaže drva, prikopava. ${ }^{41}$

\section{POJEDINI NEOBJAŠNJIVI DOGAĐAJI I POSTUPCI}

$\mathrm{K}$ azivači su uz priče u viškama, vilama i mračnjacima često donosili zanimljive podatke o nekim običajima i njima neobjašnjivim događajima.

U Veljunu je zabilježena sljedeća priča povezana sa sotonom i mogućnošću pojedinaca da ga vide: $U$ jednoga je bija uša sotona. Onda moja baba, od ćaće majka, ona je jako bogomoljna žena, ona je vjerovala u puno, onda je ona došla gori, posula je pepel po sobi di on leži, sad tamo sutradan pasji trag, ko da je pas hoda. ${ }^{42}$ E, onda dođu po popa i nije pop moga, nego mladi pop je mora, mladomisnik doć. Kad je on doša, počea je molit, gonit njega iz njega van, on je iz njega govorija. Pita kuda će. Na nožni palac van i u morske dubine, nije tija u šumu ić. Gore kud je uša, da će na usta, ne. Na nožni palac van i u dubine. Onda baba moja pita popa kako bi ga ona vidila. Stani meni doli na stopala i vidi i vidila ga je. Prema riječima kazivača sotona je u tog čovjeka ušao jer ga je majka u ljutnji zaklela. Nakon ovog događaja ova je žena mogla vidjeti sotonu i na drugim mjestima: Ona je tamo gore imala rodbinu u Krivom Putu, onda došla, išla u posjete gore, on je ovce, $u$ stalu gonija ovce, ne bi sunce sagnalo, ne daju se sagnat, a ona došla ljudi što je, pa Bog vas, vidite da van je sotona na vratin. Kako će ovce moć sotone uć. (...) Ona dode, pomoli, nešto izmoli i sotona ode, ovce za njon u štalu. (...) A sotona, Bože, oslobodi, vrag, repinu ima, jezik, rogove. (...) Vrag, znaš š to je sotona. Toga je prvo bilo dosta dok god nisu sveti sakramenti izašli. Onda su izašli sveti sakramenti pa je toga manje. Neobičan život ove žene ogleda se i u ovom dijelu kazivanja: Ona bogomoljna jako bila žena. Ona je znala kad će umrit i sinu je, ćaći mom naredila kad će umrijet i da će prid njon ić druga povorka, mrtvac, da će ić djevojka mlada, nevina prid njon. I to se nije znalo, ko je prvo zna, umrla tu na Veljunu djevojka $i$ tu se amo sastali sprovod i nosilo se na rukama, na ramenin. Sastala se oba sprovoda. Djevojka prid njon išla mrtva. Prvo rekla ćaći, sinu.

Zabilježena je i priča kako su ljudi vjerovali da dijete može osjetiti mrtvaca u selu: ...Cijelu noć je plakala, nije se moglo nikako umirit. Onda moja pokojna majka rekla-nećeš je umirit, mrtvac je u selu. I to je. Da malo dijete osjeti.

Uz djecu se vežu dvije pojedinosti koje su kazivači izdvojili kao neobične. Neki su naveli kako se smatralo da nije dobro da dječje pelene mrak zatekne na otvorenom. ${ }^{43}$ Anka Šolić Tutanova iz Šolića kazala je da su se u tom slučaju pelene ostavljale vani do sutradan, dok je Branko Tomljanović Ropeta iz Krivoga Puta iznio mišljenje da su se morale ponovno oprati ako su omrkle te je objasnio da se preko mraka može naudit djetetu. Zanimljivu priču donio je Milan Prpić Markin iz Veljuna: Da mrak onda dođe na one pelene pa da dite plače, boli ga trbuh. To san ti ja doživija. Kad se moj ovaj stariji rodija i zabolilo njega, veli to je mračina na dite, krpe su ostale vani, uvatija ih mrak, i to je sad mračina na ditetu. Snig zapa. Ajde ti sad traži negdi galebu na suvoj grani. Suvu granu i galebu, a snig do zubi. Ja san proša svita, patija se. Kad ja tu gori više kuće iđen kuci, na suvoj grani baš komad galebe. Njegova supruga Milka kaže kako se galeba, koja je prema Milanu trebala biti kravlja, stavljala u vatru te su se pelene nad njom ugrijale. Milan je kazao da će tada otić ta mračina sa diteta, što je Milka potvrdila time što se dijete smirilo.

Zabilježeno je i objašnjenje posebnog postupka kod posjeta tek rođenom djetetu. ${ }^{44}$ Naime, kazivači potvrđuju kako se pritom, da se dijete ne bi ureklo, moralo prvo pogledati u vlastite nokte, a tek nakon toga u dijete.

41 Da se pričalo kako mrtvi vuku lance, potvrdili su i Anka Šolić Tutanova iz Šolića i Grgo Prpić Miškec iz Gorice.

42 Pasji je trag kazivač objasnio kao trag sotone.

43 O ovoj pojavi govorili su: Milan Prpić Markin, Veljun; Anka Šolić Tutanova, Šolići; Ana Špalj Cucina, Krivi Put; Branko Tomljanović Ropeta, Krivi Put.

44 O tome su govorili: Zlata Tomljanović Pešina, Krivi Put; Milan Prpić Markin, Veljun; Ana Špalj Cucina, Krivi Put; Eleonora Prpić Lejina, Veljun. Ive Krmpotić Pićica iz Kuljića i Milan Krmpotić Zekonja iz Veljuna spomenuli su ovaj postupak, ali nisu naveli objašnjenje. 
Nekoliko je kazivača donijelo priče o stvarima zakopanima pod pragom za koje se vjerovalo da imaju utjecaja na zbivanja u kući. Zdenka Pavelić Vranićeva iz Pavića kazala je kako se vjerovalo da su, ako blago u kući ugiba, pod pragom zakopani uroci. Ive Krmpotić Pićica iz Kuljića je o tome ispričao ovu priču: E, sad ću ti još nešto ispričat. U Francikovcu Šojat Ivan, njemu su krave, svake godine krava krepaj. I on ti je iša u Bosnu, ovin što gataju, vračarin. I vračar njemu veli-odi ti doma, pod pragon ćeš nać nešto u štali. I on je naša neke kosti. Pod pragon u štali. To je iskopa, od toga krave nisu crkivale. To spali, sredi. ${ }^{45} \mathrm{O}$ istom je događaju, smjestivši ga u razdoblje nakon Drugoga svjetskog rata, pričao i Milan Prpić Markin iz Veljuna, s tim što je dodao kako su uz kosti bile zakopane krpice i ženska kosa. Kazivač također misli da su ljudi koji su takve stvari radili nakon smrti za kaznu postajali vampiri: A to je zakopa netko. Taj se u vampire stvorio ko je sirotinji napravio. To su ti vampiri.

Zanimljivu priču o djetetu koje je na neobjašnjiv način nestajalo iz kolijevke potvrdilo je nekoliko kazivača, smjestivši događaj u prvu polovicu 20. stoljeća. ${ }^{46}$ Dite iz koljivke uzmi, niko ne bi vidija. Odnesi u podrum. I sada dođe jedan pop molit. I kad je pop molija, on veli popu - ti se popiša u šenicu, ne možeš me izagnat. To je ćaća meni priča. Kad je doša drugi pop, drugi pop moli, iz popa znoj bacaju, vodu. Izadi van! Kud ću izać? Kroz nožni palac kud si ušao. Kad je to išlo iz te kuće, taj je pop bija sav mokar drugi. Taj nije bija grišan. A ovome je reko da se popiša u šenicu, da ga ne more. I to se ljudi celo se ovo selo sabralo i otišlo gledat. (...) To je meni tata moj pričao. Tata moj iša gledat to. Dite iz kolivke u podrum. A niko ne vidi kad dite uzme. U drugoj varijanti ove priče, koju je kazivač ispričao prema sjećanjima svog starijeg susjeda, ovaj je neobični događaj prestao kada je, nakon neuspješnog pokušaja jednog svećenika, došao biskup iz Rijeke jer takve stvari mogu riješit samo biskupi, oni su jači od popa. Običan pop to ne more riješit.

Pogled koji može ureći pojedini kazivači nisu vezali samo uz viške. ${ }^{47}$ Primjerice, Branko Tomljanović Ropeta iz Krivoga Puta kazao je kako su ljudi nastojali izbjeći susret s osobama za koje se vjerovalo da pogledom mogu nauditi. Ive Krmpotić Pićica iz Kuljića naveo je: A bili su ljudi, nije tija ić u štalu da ti vidi prase, blago, odma zbrka, nešto se dogada. To san isto čuja od svog djeda. A ti ljudi nisu ni ulazili koji su imale te, ne oči, nego imali su nešto u sebi, šta ja znan. Luka Krmpotić Brnde iz Veljuna i Grgo Prpić Miškec iz Gorice misle da je bilo i muškaraca koji su mogli ureći te se pred njima, prema kazivanju Luke Krmpotića, blago uvijek nastojalo skloniti i tako ga zaštititi. Ivan Prpić Kavarica iz Lucića također misli da su i muškarci i žene mogli imati vražje oči zbog kojih bi blago zabortalo. Neće da jide, neće da pije, neće da pase. Ovaj je kazivač također spomenuo kako se za ženu koja nije mogla imati djece reklo da je urečena. U Pavićima je zabilježeno potresno sjećanje kako je zbog pogleda jedne suseljanke malo dijete umrlo jer je ona nabacila.

Zanimljivo kazivanje o ženi koja je mogla ureći donio je Mile Prpić Popić iz Popića. Naime, prisjetio se Soke Orlić, žene iz obližnjeg pravoslavnog sela Ritavca, koja je uspjela napraviti da se konji jednog kazivačevog suseljana, nakon što je ona prošla, više nisu htjeli pomaknuti s mjesta. Nakon što je bila sama s konjem u staji, sve se popravilo. Drugom zgodom je pomogla čovjeku čiji konj nije moga pišat. Za tu joj se pomoć, prema riječima kazivača, obavezno moralo platiti. Budući da su ljudi znali da ona može ureći, nastojali su izbjeći susret s njom.

45 Kazivač se ne sjeća u kojem je mjestu u Bosni živio ovaj čovjek.

46 Ovu su priču donijeli Ive Krmpotić Pićica iz Kuljića, Milan Krmpotić Zekonja iz Veljuna i Branko Tomljanović Ropeta iz Krivog Puta. Milan Krmpotić Zekonja kazao je kako je to bilo oko sredine 20. stoljeća, dok je Branko Tomljanović Ropeta naveo vrijeme između dvaju svjetskih ratova.

47 U Upitnici Etnološkog atlasa Jugoslavije uz pitanje "Postoji li vjerovanje da neki ljudi imaju 'zlo oko' kojim mogu nanijeti nesreću, neuspjeh, bolest? Kakvi su to ljudi? (imaju npr. sraštene obrve, plave oči, razroki su ili?)” zapisano je: "Postoji vjerovanje da imade ljudi koji imadu takve oči i mogu nanijeti nesreću. Vjerojatno su to ljudi koji imadu sraštene oči". Nadalje, na pitanje "Mogu li i drugi ljudi nanijeti takvo zlo, npr. time da nešto pohvale ili nešto posebno kažu? (što?) Kako se to zove? (urok, vurok, počudište, barač ili?)” naveden je odgovor: "To se zove urok”. Objašnjava se: "Navlastito je uroku izloženo malo dijete, krava, konj, vol."; a kao zaštitni postupak navodi se: "Treba svezati nešto crveno. Neku vrpcu” (UEA, IV, 149, Fd 241/478). 
Pojedini kazivači iznijeli su neke načine zaštite i pomoći kod negativnih događaja. Ive Krmpotić Pićica iz Kuljića naveo je savjet svog djeda za slučaj da se noću nađe na otvorenom. U toj je prilici uvijek trebalo držati palac preko kažiprsta, čime bi se dobio oblik križa koji je štitio. Zlata Tomljanović Pešina iz Krivoga Puta navela je kucanje o drvo kao zaštitu od uroka: Nisi se smija začudit malon ditetu kako dobro reste, onda moraš $i$ kucnut $u$ drvo il u nešto ili blago ako vidi da blago da vidi, ako vidi nešto, e, mora si isto pokucat u drvo. To i danas se radi. A nije se smilo začudit da bi ureklo, to je bija urok, ako bi se začudili jako nečemu, to je bija urok. (...) A znalo se reć za mladenku, recimo, kada bi se začudilo da je lipa, da je zgodna, onda bi samo pokucali u drvo da je ne urekne $i$ to.

Zabilježeno je i sjećanje na ženu koja nije živjela na području Krivoga Puta, ali su ljudi iz ovih zaselaka zbog njenih sposobnosti odlazili k njoj kad bi im zatrebala pomoć. Radi se o Mandici Lućanki, pravoslavki koja je živjela u Lučanima kod Brinja. Priča kaže: Kad si doša kod nje, Spasitelj je, visila velika slika i Spasitelja govorilo. On joj reci što će biti i on joj prenesi. Ona ti prenosi. Zabilježeno je kako je jednom prilikom pomogla čovjeku koji je imao epilepsiju, kao i bolesnoj kravi kazivačeve bake. Mandica je kod njenog dolaska već znala dio razgovora koji je ona sa susjedom vodila putem do nje. Rekla joj je: "I odi kući i nać ćeš komšiju, pomuzla je kravu, popit ćeś bijelu kavu kad dođeš kući." Kad ona kući, krava se digla, pomuzla žena kravu i skuhala bijelu kavu. Prema riječima kazivača za svoju pomoć Mandica nikada nije tražila naknadu: Ništa. Ne daj, Bože, da bi uzela ni kave.

\section{ZAKLJUČAK - ONI STARI LJUDI PRIPOVIDAJ, A MI SLUŠAJ ${ }^{48}$}

$\mathrm{P}$ riče zabilježene o vjerovanjima u nadnaravna bića i neobjašnjive pojave i danas žive među stanovništvom Krivoga Puta. Prenošene s generacije na generaciju, čine dio duhovne kulture stanovništva ovog kraja o kojoj su tijekom istraživanja kazivači vrlo rado pričali.

Ipak, danas priče imaju drugačiji život. Luka Krmpotić Brnde iz Veljuna kazao je kako su priče prestale otkad je ovaj priokret, misleći pritom na razdoblje nakon Drugoga svjetskog rata: To onda, negda spominjalo, sad se ne spominje više niko ni o vilama ni o ničemu. (...) A šta ja znan, izašlo iz običaja. Anka Prpić Brunićeva iz Krivoga Puta također je kazala kako su ove priče pripovijedale babe stare, koje bi pričale o svemu, a kad je ona već poodrasla, to se promijenilo: Nismo vjerovali, nije niko vjerova u to, pa se nije ni pričalo. Ova kazivačica tako, nestajanje priča povezuje s time što ljudi više nisu vjerovali u postojanje nadnaravnih bića, na što je ukazao i Tome Špalj Cucin iz Krivoga Puta rekavši: Kako je to sve skupa sada malo bolje što se tiče nauke i malo više je prosvijećen narod, tako da se manje u to vjeruje.

Neke od priča zabilježenih na području Krivog Puta predstavljaju osobna iskustva, susrete s nekim od opisanih bića, a neke su tek dio predaja koje su kazivači čuli od svojih starijih, kako to objašnjava Ivan Prpić Kavarica iz Lucića: To je bilo tih starijih ljudi, onda bi sastali te mladeži, nije bilo tog nešto drugoga, zimi, to saberi se ta mladež i taj je bio starac koji je zna to govorit. Iako se vjerovanja u nadnaravna bića, pojedinosti o njihovoj pojavnosti, sposobnostima i mogućoj zaštiti od njihova utjecaja te osobna iskustva i sjećanja vezana uz svako pojedino biće ili neobjašnjiv događaj razlikuju, ono što ih sve povezuje jest priča. Ta priča sastavljena je od, ponekad vrlo različitih elemenata sjećanja, iskustva, događaja, razmišljanja, vjerovanja, pri čemu je pitanje, jesu li nadnaravna bića doista postojala, za same kazivače manje važno od pitanja jesu li ljudi o njima pričali, jesu li ih, kako kaže Luka Krmpotić Brnde iz Veljuna, spominjali. Zbog toga se, i ovim istraživanjem, nastojala obuhvatiti sva raznolikost priča koje i danas žive, premda se njima više ne straše dica ${ }^{49}$, već one čine dio duhovne kulture područja Krivoga Puta.

Riječi Mile Prpića Popića iz Popića.

49 Ovu je karakteristiku priča o vilama, viškama i drugim nadnaravnim bićima posebice naglasila Ana Špalj Cucina iz Krivoga Puta. 


\section{LITERATURA I IZVORI:}

ŠKRBIĆ, Nevena (2001): Izvješće s istraživanja u selima pod Senjskim bilom i u zaleđu Sv. Jurja. Senjski zbornik, 28:261-274, Senj.

Upitnice Etnološkog atlasa (UEA), Svezak IV., teme broj: 141. Mora, vampir, vukodlak i neka slična bića, 142. Vjestice, vile, sudenice, 143. Neka druga natprirodna bića i pojave, 149. Zlo oko, uroci, sretni i nesretni dani; Arhiv Odsjeka za etnologiju i kulturnu antropologiju, Filozofski fakultet u Zagrebu. 